\title{
Laser lithotripsy - The new wave
}

\author{
J HOCHBERGER, MD, C ELL, MD, FRCPC
}

\begin{abstract}
Currently more than $90 \%$ of all common bile duct concrements can be removed via the endoscopic retrograde route by means of endoscopic papillotomy, stone extraction by baskets and balloon catheters, or mechanical lithotripsy. Oversized, very hard or impacted stones however often still resist conventional endoscopic therapy. Laser lithotripsy represents a promising new endoscopic approach to the nonsurgical treatment of those common bile duct stones. Currently only short-pulsed laser systems with high power peaks but low potential for thermal tissue damage are used for stone fragmentation. Systems in clinical application are the pulsed free-running-mode neodymium YAG (Nd:YAG) laser (1064 nm, $2 \mathrm{~ms}$ ) and the dye laser ( $504 \mathrm{~nm}, 1$ to $1.5 \mu \mathrm{s})$. Energy transmission via highly flexible $200 \mu \mathrm{m}$ quartz fibres allows an endoscopic retrograde approach to the stone via conventional duodenoscope or motherbaby-scope systems. New systems currently in preclinical and first clinical testing are the Q-switched Nd:YAG laser (1064 nm, $20 \mathrm{ns)}$ and the Alexandrite laser ( 700 to $815 \mathrm{~nm}, 30$ to $500 \mathrm{~ns}$ ). By means of extremely short nanosecond pulses $\left(10^{-9} \mathrm{~s}\right)$ for the induction of local shock waves at the stone surface, possible tissue damage is even more reduced. No complications have been reported so far after applying laser lithotripsy clinically in about 120 patients worldwide. Compared to extracorporeal shock wave treatment, laser lithotripsy can be executed in any endoscopy unit in the scope of the endoscopic pretreatment and does not require general anesthesia, which is often necessary for extracorporeal shock wave lithotripsy. Can J Gastroenterol 1990;4(9):632-636
\end{abstract}

Key Words: Alexandrite laser, Cholelithiasis, Common bile duct, Dye laser, Laser, Lithotripsy, Neodymium YAG laser, Shock waves

\section{La lithotritie au laser}

RESUME: Actuellement, plus de $90 \%$ des calculs du cholédoque peuvent être éliminés par voie rétrograde endoscopique au moyen d'une papillotomie endoscopique, par sonde à panier et à ballonnet ou par lithotritie mécanique. Néanmoins, les calculs volumineux, calcifiés ou enclavés, résistent souvent fréquemment à la thérapie endoscopique traditionnelle. La lithotritie au laser représente une nouvelle approche endoscopique prometteuse dans le traitement non chirurgical de ces calculs cholédociens. Présentement, seuls les laser à impulsion courte permettant d'atteindre des crêtes d'énergies importantes sans endommager les tissus sont utilisés dans la fragmentation des calculs. Les appareils servant aux applications cliniques sont le laser YAGnéodyme (NdYAG) en oscillation libre (1064 nm, $2 \mathrm{~ms}$ ) et le laser à colorants ( $504 \mathrm{~nm}, 1$ à 1,5 $\mu \mathrm{s})$. La transmission d'énergie s'effectue par des fibres de quartz de $200 \mu \mathrm{m}$ très flexibles

Friedrich-Alexander-University, Erlangen-Nuremberg, Germany

Correspondence and reprints: Dr J Hochberger, Department of Medicine I, Krankenhausstr. 12, Friedrich-Alexander-University Erlangen-Nuremberg, D-8520 Erlangen, Germany
$\mathrm{S}$ INCE THE EARLY 1980s SEVERAL teams have worked on the problem of fragmentation of gallstones by laser $(1-19)$. First reports on the percutaneous-transhepatic lithotomy of common bile duct stones came from Japan using a continuous wave neodymium YAG (Nd:YAG) laser, as it is known in endo. scopic tumour treatment $(1,2)$. Mainly, melting and drilling effects on the stone could be obtained. The high risk of thermal damage to surrounding tissue in case of accidental irradiation using the continuous wave laser prevented a further development of this method.

Currently, only short-pulsed laser systems emitting milli- to nanosecond pulses $\left(10^{-3}\right.$ to $\left.10^{-9} \mathrm{~s}\right)$ are used (Figure 1). The advantage of pulsed lasers com. pared to the continuous wave lasercon. sists in the fact that due to short pulse duration high power peaks can be reached. The pulse energy ( $E_{p}$, power $x$ pulse duration) and the mean power $\left(\mathrm{P}_{\mathrm{m}}\right.$, pulse energy $X$ pulse repetition rate), measures for the thermal poten. tial of the laser are, however, low. In 1986 common bile duct stones could be disintegrated for the first time in man via the endoscopic retrograde route by means of a pulsed Nd:YAG laser $(5,6)$. In the meantime, experiences of other groups have been reported mostly ap. plying the pulsed dye laser $(7,8)$. How. ever, to date only about 120 patients have been treated worldwide with this new therapy concept, which is still an experimental clinical treatment. Cettain problems concerning the laser lithotriptor devices, the endoscopic approach and energy application in the bile duct account for this fact. 
autorisant l'approche des calculs par voie rétrograde endoscopique, à l'aide d'un duodénoscope conventionnel ou d'un foetoscope. Les nouveaux modèles présentement utilisés lors des premiers essais cliniques ou des essais précliniques sont le laser NdYAG Q-commuté, c'est-à-dire en fonctionnement à facteur de surtension commuté (1064 nm, $20 \mathrm{~ns})$, et le laser à alexandrite (700 à $815 \mathrm{~nm}$, 30 à $500 \mathrm{~ns})$. La production d'impulsions extrêmement brèves $\left(10^{-9} \mathrm{~s}\right)$, provoquant l'induction d'ondes de choc locales à la surface des calculs, permet encore de réduire l'éventualité des lésions tissulaires. Aucune complication n'a été rapportée jusqu'à ce jour chez les 120 patients ayant subi une lithotritie au laser dans divers pays du monde. Comparée à la lithotritie extracorporelle par ondes de choc, la lithotritie au laser peut être réalisée dans toute unité d'endoscopie dans le cadre d'un prétraitement endoscopique; elle ne requiert pas d'anesthésie générale, souvent nécessaire dans le cas de la LEOC.

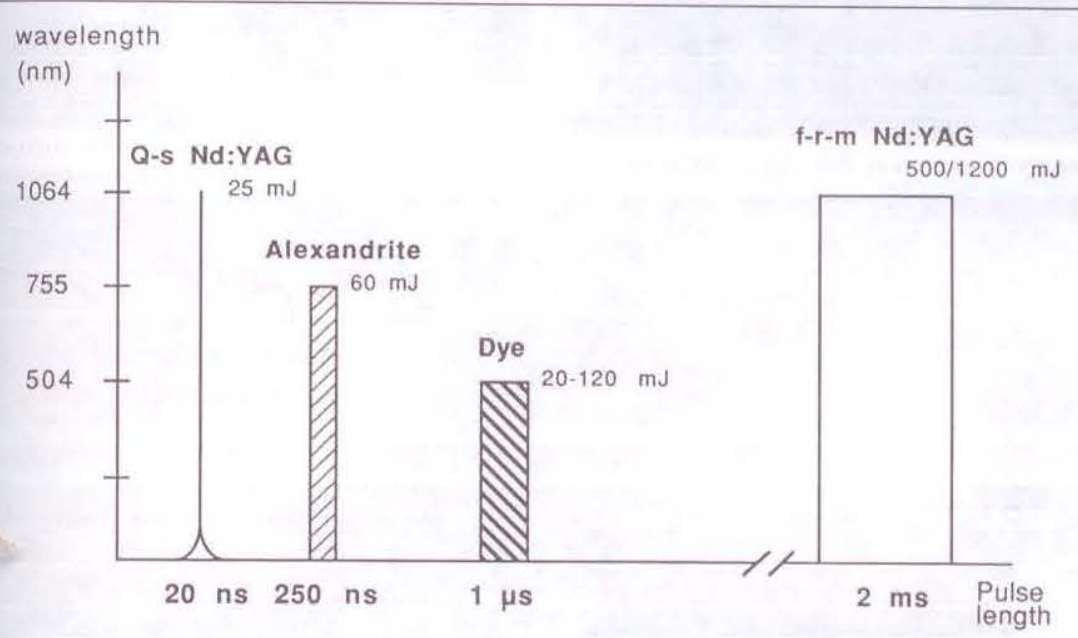

Figure 1) Characteristics of four pulsed laser systems currently in preclinical and clinical use for the laserlithotripsy of gallstones. Q-s Quality switched; $f-r-m$ Free-running mode

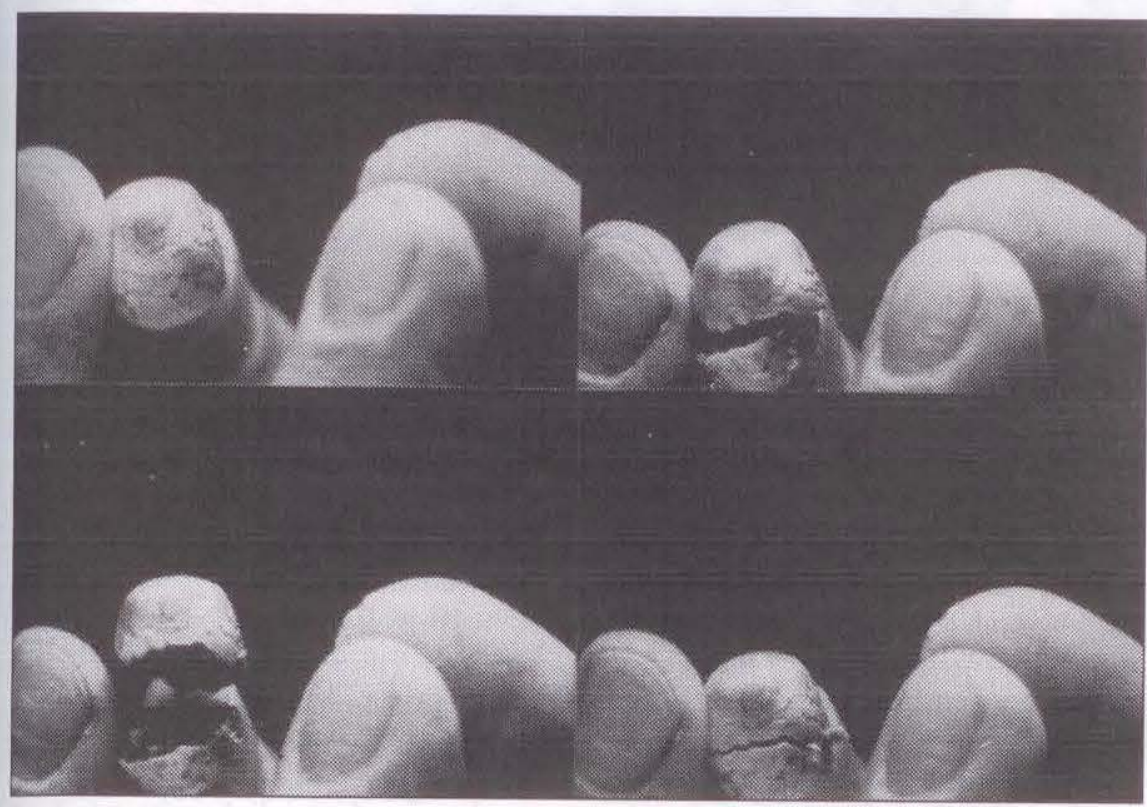

Figure 2) Gallstone fragmentation within a few seconds using the millisecond pulse free-running mode Nd:YAG laser
For clinical application in gastroenterology, the only laser systems at present commercially available are pulsed dye and Nd:YAG lasers. The Alexandrite laser is currently being subjected to preclinical testing (9). Excimer, ErbiumYAG, frequency doubled Nd:YAG and Titan-Sapphire lasers may be interesting lithotripsy systems for the future but require further technical develop. ment at present.

The pulsed Nd:YAG laser is a solid state laser emitting near infrared light (usually $1064 \mathrm{~nm}$ wavelength). Two different pulse qualities are used for laser lithotripsy: ms pulses $\left(10^{-3} \mathrm{~s}\right)$ generated in the free-running operation mode and ns pulses $\left(10^{-9} \mathrm{~s}\right)$ generated in the Q-switched operation mode. The system the author's group is using (Lasolith; LASAG AG, Thun, Switzerland) offers both pulse qualities.

The free-running mode $\mathrm{Nd}$ :YAG laser produces light pulses up to some thousands of watts in a period of $2 \mathrm{~ms}$. The light transmission system consists of a simple highly flexible $200 \mu \mathrm{m}$ quartz fibre brought into direct contact with the stone. After guiding the fibre with laser pulses of lower energy $(0.5 \mathrm{~J} / 4$ $\mathrm{Hz}$ ) to the centre of the stone, the pulse energy is augmented $(1.3$ to $2.0 \mathrm{~J} / 4 \mathrm{~Hz})$. That way even giant calculi can be disintegrated into two to five larger fragments within seconds ( 5 to $90 \mathrm{~s}$ ) (Figure 2 ). The fragmentation mechanism is based on the formation of high vapour pressures at the fibre tip which make the stone break up from its centre. Due to relatively high pulse energies, discrete thermal lesions of tissue in contact with the $200 \mu \mathrm{m}$ fibre tip are possible. However, chronic experiments in dogs showed no complications in clinical

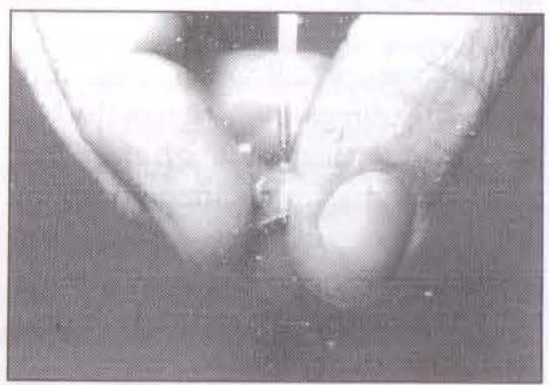

Figure 3) Removal of fine fragments from the stone surface by laser-induced local shock waves with the Q-switched Nd:YAG laser 


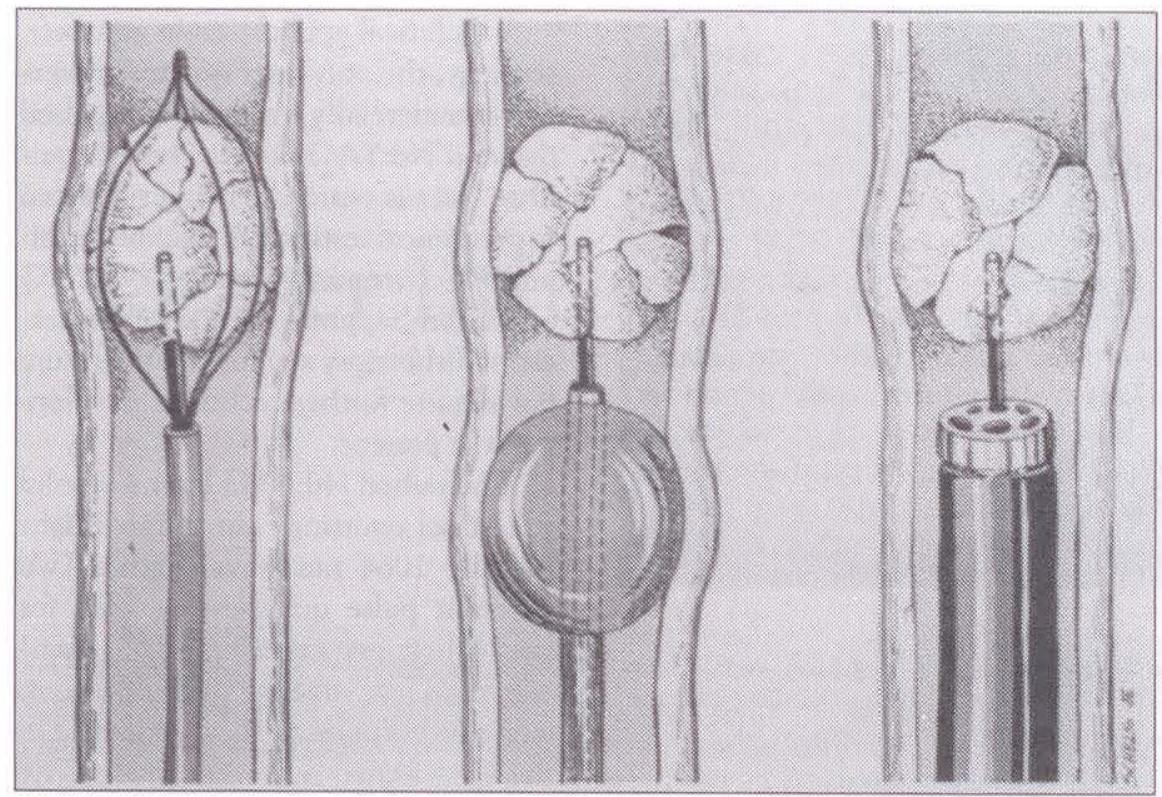

Figure 4) Three different ways of applying laser energy to common bile duct concrements: choledochoscope (left), balloon catheter (centre) with concentric fibre channels, and special lithotriptor basket (right)
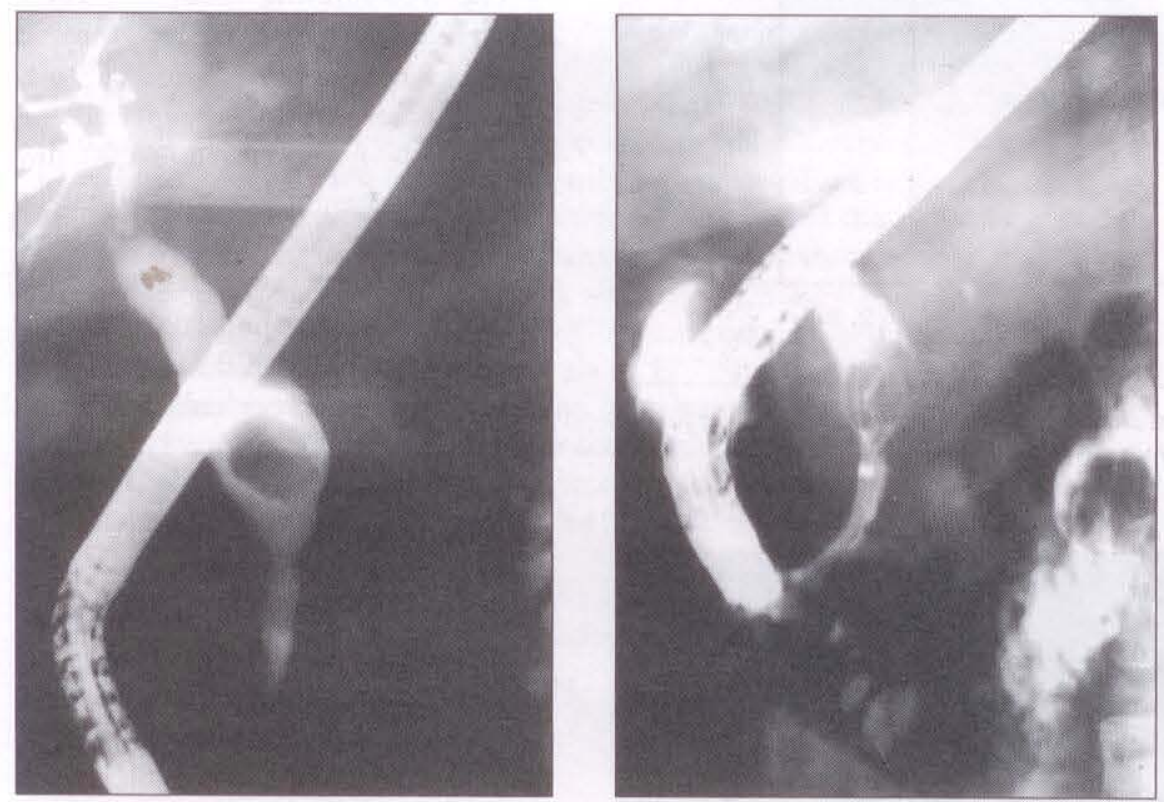

Figure 5) Nonextractable very hard common bile duct concrement in which mechanical lithotripsy had failed several times radiologically before (left) and after laser lithotripsy using the lithotriptor basket; clearly visible fracture line through the centre of the stone (right)

and laboratory follow-up until four weeks after direct irradiation of the bile duct. Histological findings after that time were basically inconspicuous $(10,11)$. Due to its fragmentation mechanism, the free-running mode Nd:YAG laser can be used for gallstones but not for kidney stones.

In the Q-switched operation mode, the pulsed Nd:YAG laser produces extremely high power peaks up to the gigawatt range $\left(10^{9} \mathrm{~W}\right)$ within five to 30 ns. However, the pulse energy product of laser power and pulse duration, as well as the mean power of the laser are low ( $E_{\mathrm{p}} 15$ to $25 \mathrm{~mJ} ; \mathrm{P}_{\mathrm{m}}$ around 0.3 W). With this laser type, nonlinear optical processes such as 'plasma' induction and creation of a local shock wave can be induced. By this method a completely athermal transformation of light energy into mechanical energy is possible (20).
Due to high power peaks of the 'giant pulses' of the Q-switched Nd:YAG laser, initially only relatively rigid fibre transmission systems could be used. The fibre core diameter was at least $600 \mu \mathrm{m}$, and an additional lens focusing system or 'light pipes' at the distal fibre end were needed $(12,13)$. The authors have developed a highly flexible $300 \mu \mathrm{m}$ quartz light guide system which permits endoscopic retrograde application of the Q-switched Nd:YAG laser (14). By giving the distal fibre end a lens-like hemispherical configuration, a focus area 1.5 to $3 \mathrm{~mm}$ in front of the fibre tip is obtained. An additional lens focusing system is not necessary. The laser plas. ma at the point of origin of the mechanical shock wave is induced either in front or directly on the surface of the concrement. Stone disintegration results from the removal of very fine sand grain or powder-like frag. ments from the stone surface (Figure 3). There is no hazard of thermal damage to tissue applying this laser type.

In the flash lamp pulsed dye laser, organic dyes mostly dissolved in alcohol are used as active laser material. Depending on the specific dye and the resonator setting, the wavelength of the emitted laser beam can be varied be tween the far ultraviolet and the near infrared (tunability of wavelength). Best light absorption in gallstones and kidney stones is obtained in the bluegreen light spectrum $(4,15,16)$. For this reason, the $504 \mathrm{~nm}$ wavelength is commonly applied, which can easily and effectively be generated using cumarin dye and which is less absorbed in hemoglobin than in bilirubin. The high absorption of biliary concrements for light of this wavelength facilitates the induction of a laser plasma with the relatively long microsecond $\left(10^{-6} \mathrm{~s}\right)$ light pulses of the dye laser. The frag. mentation process itself is athermal but induced by a thermal process $(16,17)$. After heating a small quantity of stone material at the tip of a $200 \mu \mathrm{m}$ fibre brought into direct contact with the stone surface, the plasma and consequently the mechanical shock wave is induced. The result of fragmentation is similar to that of the Q-switched Nd:YAG laser. The advantage of the 

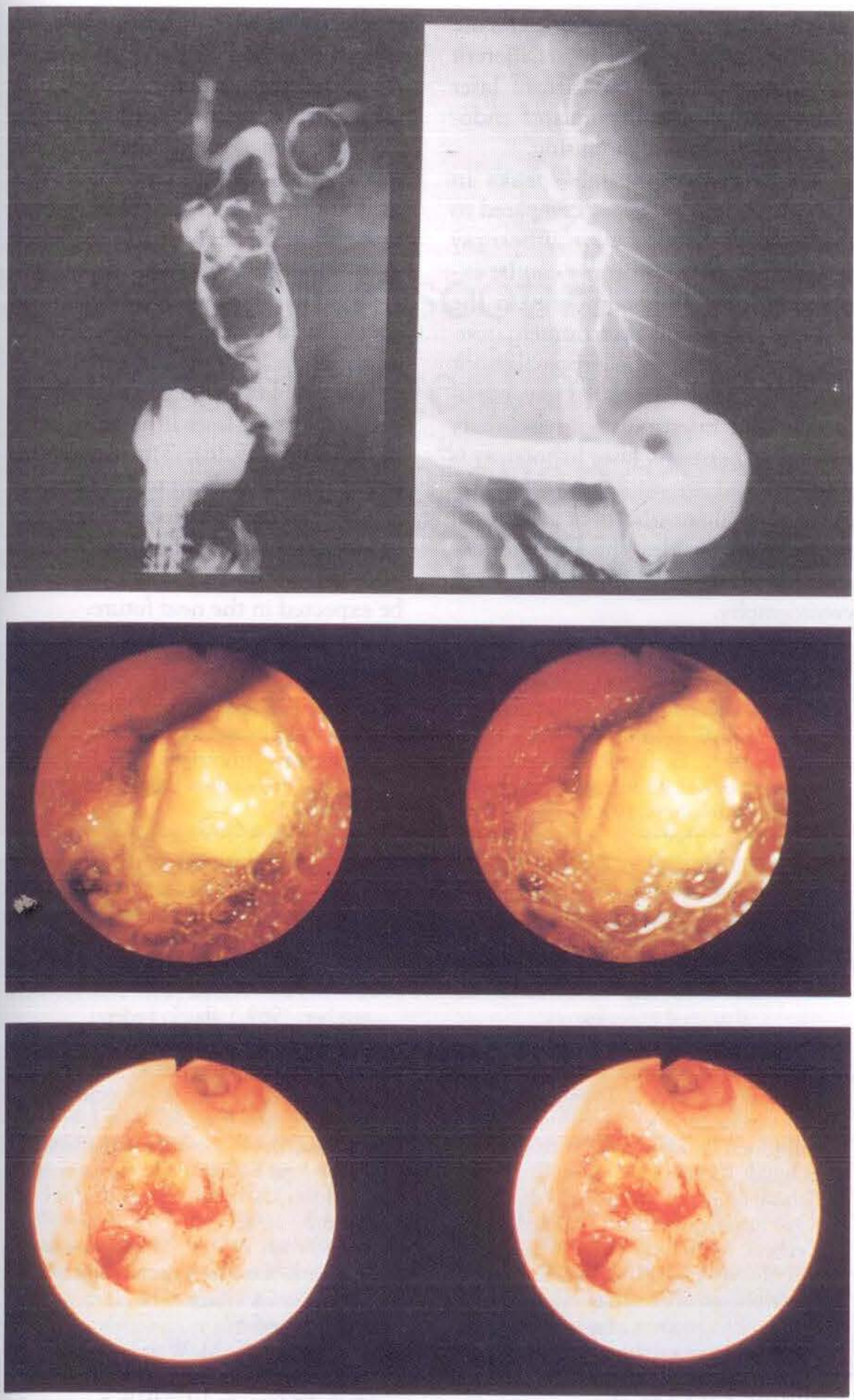

Figures 6-9) Radiologic and choledochoscopic findings before and after laser lithotripsy of a giant common bile duct concrement with visualization of the intrahepatic bile ducts after successful stone removal

dye laser lies in its simple fibre transmission system, corresponding to that of the free-running mode Nd:YAG laser and the use of low pulse energies $\left(E_{p} 30\right.$ to $90 \mathrm{~mJ} ; \mathrm{P}_{\mathrm{m}} 0.3$ to $1.3 \mathrm{~W}$ ). Contrary to the nanosecond pulse Q-switch $\mathrm{Nd}$ :YAG, the dye laser can induce thermal tissue damage. Currently existing type for the fragmentation of biliary calculi are still limited. A solid state laser like the Nd:YAG, the Alexandrite laser should be reliable in operation and easy to maintain. Similar to the dye laser it is tunable within a certain wavelength range ( 700 to $815 \mathrm{~nm}$ ) but is additionally tunable in pulse duration (30 to $500 \mathrm{~ns}$ in the Q-switched operation mode). As the laser radiation emitted is in the deep red and near infrared, low absorption in tissue and therefore little damage is expected. Sufficient absorption in stone pigments, however, leads to a fragmentation effect approximately comparable to that of the pulsed dye laser at equal pulse energies (9). Because of great loss of quartz material from the fibre tip at short pulse length ( $250 \mathrm{~ns})$, electronic 'pulse stretching' to the microsecond range seems to be favorable (19). In vitro and animal experiments in rabbits to reveal possible tissue damage to the bile duct using the Alexandrite laser are presently under way.

\section{CLINICAL APPLICATION}

At present there are three different methods for endoscopic retrograde application of laser lithotripsy in the common bile duct (5-10) (Figure 4).

If the stone can be caught in a lithotripter basket, it can be fragmented under $\mathrm{x}$-ray control alone; the fibre is centred right in the middle of a laser basket by means of a central channel without any danger of accidental application of energy to surrounding tissue (Figure 5). In the case of impacted stones a similar idea is pursued using a balloon catheter with a central channel. Since $\mathrm{x}$-ray control can usually be done only in two planes, a certain insecurity will remain concerning the correct energy application even if balloon catheters are developed which are better adapted to the anatomical situation. Without any doubt, the safest approach for stone fragmentation is the use of a 'baby' or 'mini' endoscope which is inserted into the bile duct via a 'motherscope'. The disadvantage of the so far commercially existing mother-babyscope systems is, however, that they are fragile and their application is not always simple depending on 
the anatomical situation of the bile duct.

\section{CONCLUSIONS}

Extracorporeal shock wave lithotripsy, endoscopic electrohydraulic lithotripsy or chemical dissolution via nasobiliary tubes are alternatives for the nonsurgical treatment of common bile duct stones which cannot be removed by standard endoscopic procedures (21). Whether laser lithotripsy will become a strong competitor to existing treatment techniques depends on different factors. First, laser lithotripsy systems commercially available at present should be easier to handle and greatly reduced in price. Furthermore, endoscopic equipment for laser lithotripsy such as miniscopes or special baskets

\section{REFERENCES}

1. Orii K, Nakahara A, Takase Y, Ozaki A, Sakita T, Iwasaki Y. Choledocholithotomy by YAG laser with a choledochofiberscope; Case reports of two patients. Surgery 1981;90:120-1.

2. Orii K, Ozaki A, Takase Y, Iwasaki Y. Lithotomy of intrahepatic and choledochal stones with YAG laser. Surg Gynecol Obstet 1983;156:485-7.

3. Mills T, Swan P, Watson G, Bown SG, Salmon PR. Comparison of thermal and photoacoustic fragmentation of biliary calculi using continuous wave and giant pulse lasers. Laser Surg Med 1983;3:156. (Abst)

4. Watson G, Jaccques S, Dretler S, Parrish J. Tunable pulsed dye laser for fragmentation of biliary calculi. Laser Surg Med 1985;5:189. (Abst)

5. Lux G, Ell C, Hochberger J, Müller D, Demling L. The first successful endoscopic retrograde laser lithotripsy of common bile duct stones in man using a pulsed neodymium YAG-laser. Endoscopy 1986;18:144-5.

6. Ell C, Lux, G, Hochberger J, Müller D, Demling L. Laserlithotripsy of common bile duct stones. Gut 1988;29:746-51.

7. Kozarek RA, Low DE, Ball TJ. Laserlithotripsy of large bile duct stones. Gastrointest Endosc 1988;28:418-21.

8. Cotton PB, Kozarek RA. Laser lithotripsy of large bile duct stones under direct vision via peroral choledochoscopy. Gut 1988;29:1496. (Abst)

9. Hochberger J, Wisbacher R, Gruber E, Hahn EG, Ell C. Lithotripsy of gallstones using four different laser sys- must be miniaturized or modified for use over standard duodenoscopes. Different developments and activities of laser companies or manufacturers of endoscopy equipment are promising.

The argument which speaks in favour of laser lithotripsy compared to extracorporeal shock wave lithotripsy (22) is that laser lithotripsy can be executed in any endoscopy unit in the scope of endoscopic pretreatment, usually necessary for extracorporeal shock wave lithotripsy (contrast $\mathrm{x}$-ray, papillotomy and insertion of a nasobiliary tube). Furthermore, laser lithotripsy is painless and therefore does not require general anesthesia or additional medication besides the usual endoscopic retrograde cholangiopancreatography.

tems: Alexandrite-, dye-, free-running mode neodym YAG- and $Q$-switched neodym YAG-laser in vitro. In: Ell C, Marberger M, Berlieu P, eds. Extra und intracorporale Lithotripsie. Stuttgart: Thieme Publishers, 1990.

10. Ell C. Laserlithotripsie von Gallensteinen. In vitro-und tierexperimentelle Untersuchungen. Stuttgart: Ferdinand Enke Publishers, 1988.

11. Ell C, Hochberger J, Müller D, et al. Laserlithotripsy of gallstones by means of a pulsed neodymium YAG-laser - In vitro and animal experiments.

Endoscopy 1986;18:92-4.

12. Ell C, Wondrazek F, Frank F, Hochberger J, Lux G, Demling L. Laser-induced shockwave lithotripsy of gallstones. Endoscopy 1986;18:144-5.

13. Schmidt-Kloiber H, Reichel E, Schöffmann H. Laserinduced shockwave lithotripsy (LISL). Biomed Technik 1985;30:173-81.

14. Hochberger J, Ell C, Gruber E, et al. Laserlithotripsy of biliary calculi by means of a Q-switched giant pulse Nd:YAG laser and highly flexible fiber systems. Gastroenterology 1989;96:A213. (Abst)

15. Nishioka N, Anderson R. Fragmentation of biliary calculi with tunable dye lasers. Gastroenterology 1986;32:157. (Abst)

16. Nishioka N, Levins P, Murray S, Parrish J, Anderson R. Fragmentation of biliary calculi with tunable dye lasers. Gastroenterology 1987;93:250-5.

17. Nishioka NS, Teng P, Deutsch TF, Anderson R. Mechanism of laserinduced fragmentation of urinary and biliary calculi. Lasers Life Sci 1987;231-
Electrohydraulic lithotripsy is a very effective method for the disintegration of very hard or giant biliary calculi (21). Nevertheless, there is always a potential for tissue damage up to immediate per. foration of the bile duct wall under frag. mentation $(23,24)$. On the contrary, however, complications in the clinical use of laser lithotripsy have not been reported so far, irrespective of the laser system used.

Easier and less invasive approaches to the gallbladder could open up new perspectives for laser lithotripsy in the near future $(25,26)$. The use of thin light guide fibres down to $350 \mu \mathrm{m}$ over. all diameter are a plus for laser lithotrip. sy compared to electrohydraulic or ultrasound lithotripsy. Pilot studies can be expected in the near future.

45.

18. Steiger E, Kuper JW. A Q-switched Alexandrite-laser for laser induced shock wave lithotripsy (LISL) - Basics and in vitro studies. Laser Med Surg 1988;2:43-7.

19. Engelhardt R, Brinkmann R, Meyet W, Walling J, Heller D. Urinary and biliary stone fragmentation with the Alexandrite-Laser. International Congress and Workshop on Laserlithotrip. sy and Conventional Therapy of Urinary and Biliary Stone Disease. Sep. tember, 1989, Lübeck, Federal

Republic of Germany. (Abst)

20. Boulnois J. Photophysical processes in recent medical laser developments: A review. Lasers Med Sci 1986;1:47-66.

21. Classen M, Hagenmüller F, Knyrim K, Frimberger E. Giant bile duct stonesNon-surgical treatment. Endoscopy 1988;20:21-6.

22. Sauerbruch T, Stern M. Fragmentation of bile duct stones by extracorporeal shock waves. Gastroenterology 1989;96:146-52.

23. Koch H, Stolte M, Walz V. Endoscopic lithotripsy in the common bile duct. Endoscopy 1977;9:95-8.

24. Liguory CL, Bonnel D, Canard JM, Cornud F, Dumont JL. Intracorporeal electrohydraulic shock wave lithotripsy of common bile duct stones. Endoscopy 1987;19:237-40.

25. Kellett MJ, Wickham JEA, Russell RCG. Percutaneous cholecystolithotomy. Br Med J 1988;296:453-5.

26. Wenk H, Thomas S, Schmeller N, Lange V, Schildberg FW. Percutaneous transhepatic cholecysto-lithotripsy (PTCL). Endoscopy 1989;21:221-2. 


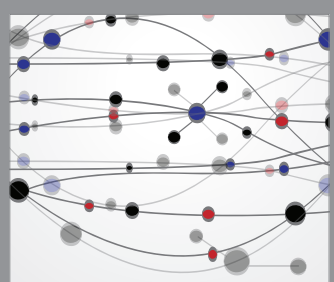

The Scientific World Journal
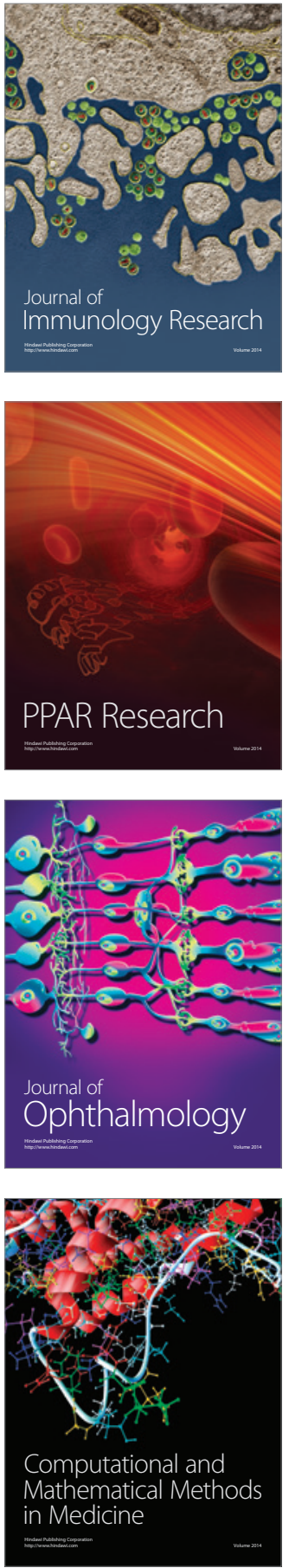

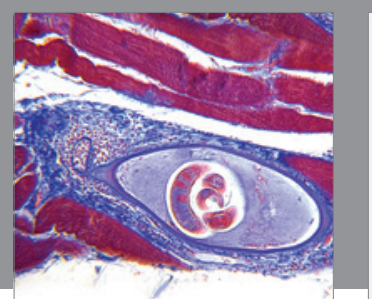

Gastroenterology Research and Practice

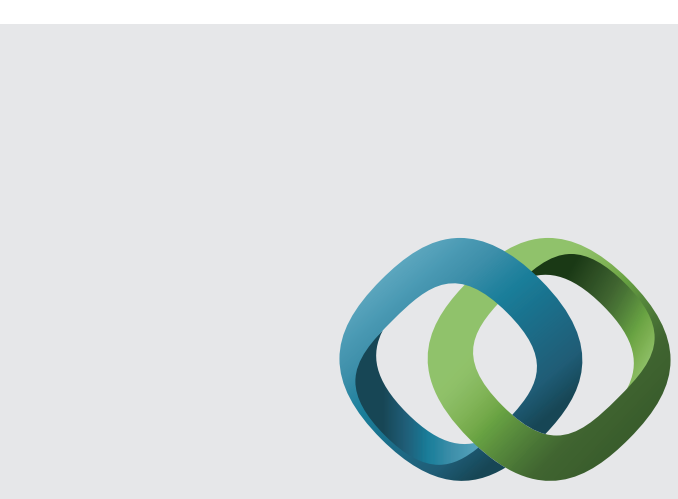

\section{Hindawi}

Submit your manuscripts at

http://www.hindawi.com
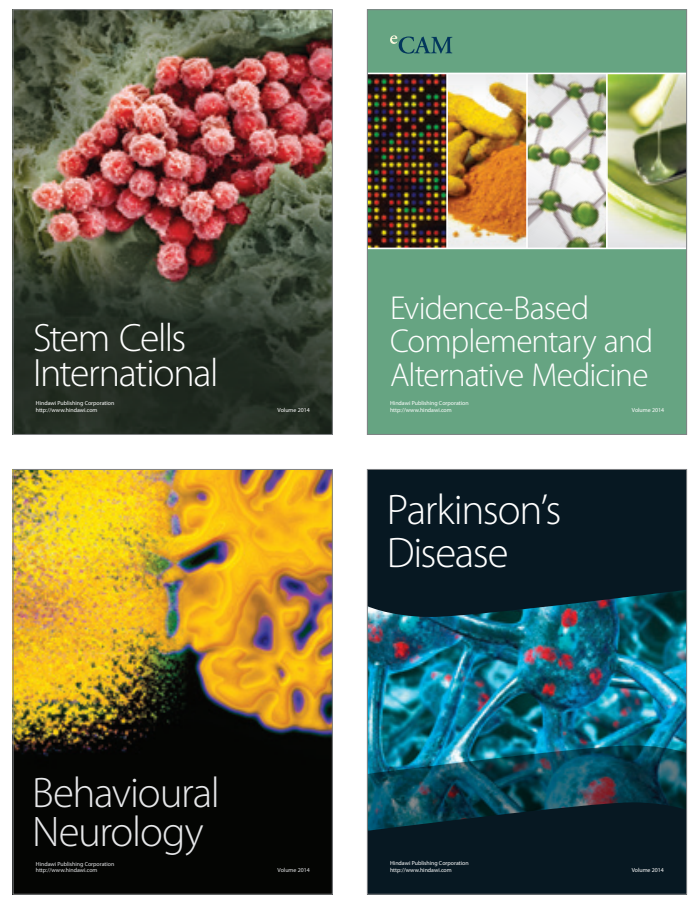
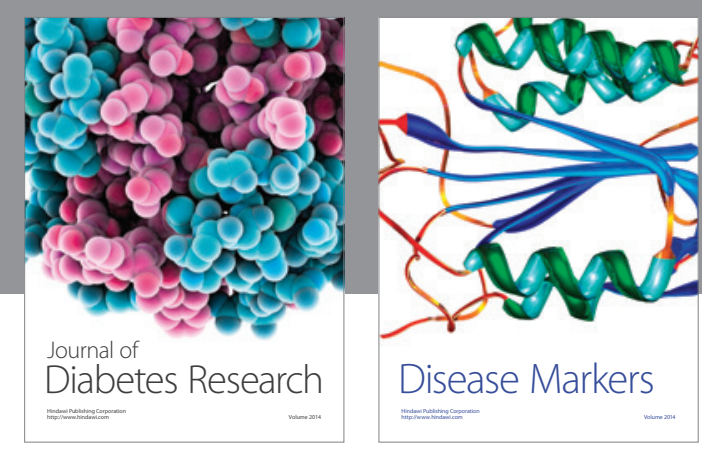

Disease Markers
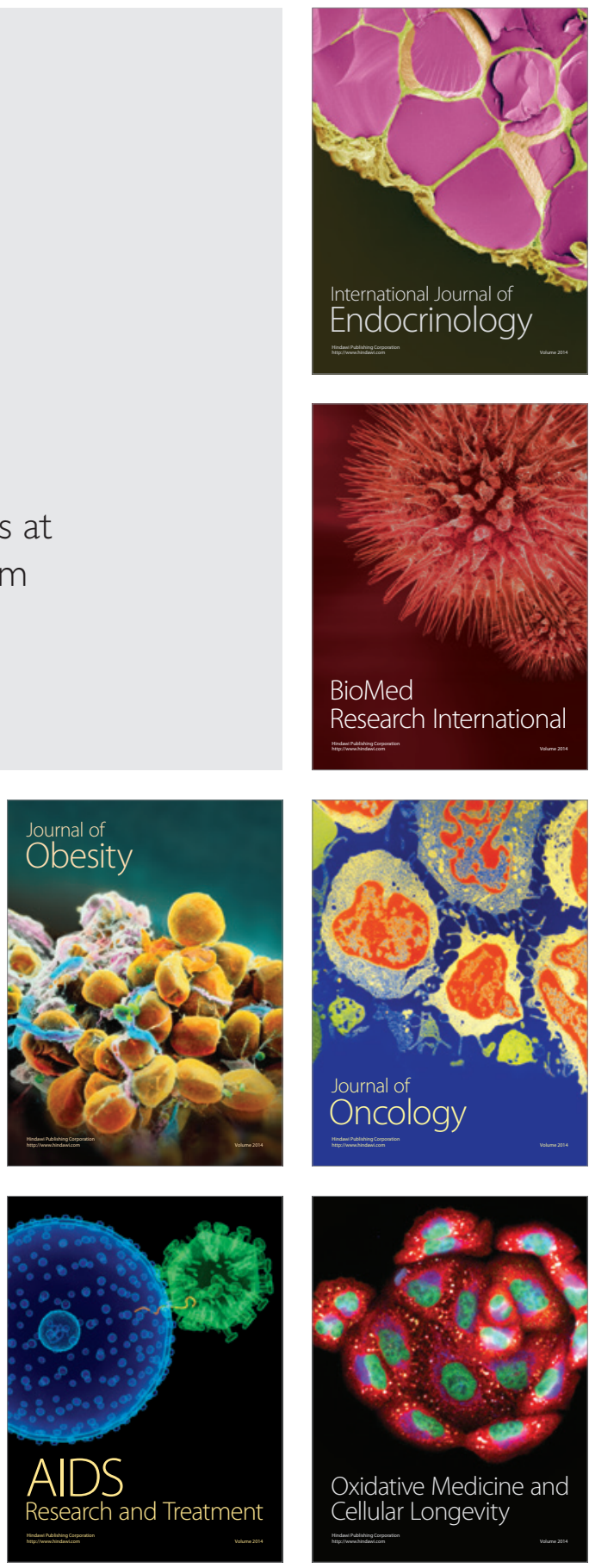